\title{
Węzły chłonne związane z regionalnym szerzeniem się niedrobnokomórkowego raka płuca - topografia, metody obrazowania i diagnostyka inwazyjna
}

\author{
Mateusz Polaczek ${ }^{1,2}$, Hanna Dobaczewska ${ }^{1}$, Adam Peryt ${ }^{3}$, Inga Barańska ${ }^{4}$, Jacek Zych ${ }^{2}$, \\ Tadeusz Orłowski ${ }^{3}$, Bogdan Ciszek ${ }^{1}$, Iwona Bestry ${ }^{4}$, Kazimierz Roszkowski-Śliż ${ }^{2}$
}

Poszczególne grupy węzłów chłonnych zaangażowane w regionalny odpływ chłonki z płuca zostały wyróżnione na podstawie danych klinicznych na potrzeby oceny zaawansowania niedrobnokomórkowego raka płuca, a podział ten odbiega od przedstawianego w podręcznikach klasycznej anatomii. Aktualna klasyfikacja International Association for the Study of Lung Cancer wyróżnia 14 oddzielnych grup węzłów chłonnych, z czego grupy 1, 2, 4, 8-14 są węzłami parzystymi (strony prawej i lewej). Poszczególna grupa węzłów chłonnych ma swoją szczegółową charakterystykę topograficzną. Większość płuca drenowana jest poprzez sieć podopłucnowych naczyń chłonnych do węzłów grupy 10 i 11, które najczęściej stanowią pierwszą stację dla szerzenia się przerzutów. Kolejnymi grupami zaangażowanymi w odpływ chłonki są węzły śródpiersia. Dane te przekładają się na ocenę zaawansowania nowotworu (staging) zgodnie z klasyfikacją TNM. W poniższym artykule omawiamy szczegółową topografię poszczególnych grup węzłowych, klasyczną oraz alternatywne drogi odpływu chłonki z płuc, przy czym tłumacząc wiele zaskakujących klinicznych obserwacji w szerzeniu się przerzutów, prezentujemy metody obrazowania w tomografii komputerowej oraz użyteczność pozytonowej tomografii emisyjnej. Artykuł przedstawia również możliwość inwazyjnej diagnostyki omawianych grup węzłów - techniki mediastinoskopii oraz coraz szerzej rozpowszechnione endoskopowe metody małoinwazyjne.

\section{Lymph nodes associated in regional spread of non-small cell lung cancer metastases - topography, imaging and invasive diagnostic methods}

Each group of hilar and mediastinal lymph nodes was defined because of specific clinical needs in terms of non-small cell lung cancer lymphatic spread patterns. This classification varies from the one found in anatomy textbooks. The most up-to-date classification was presented by the Association for the Study of Lung Cancer and it describes fourteen separate groups of nodes, in which lymph node groups 1, 2, 4, 8-14 are paired (i.e. right and left sided). Each group has its own characteristics. Most lung tissue is drained throughout subpleural lymphatic vessels to eventually meet in hilar nodes of groups 10 and 11, which are said to be most often the prime station for lung cancer metastases. Next, the lymph runs to mediastinal lymph nodes. This phenomenon has its consequences in TNM classification of lung cancer. In this article we describe detailed topographical features of each lymph node group, present normal and alternative pathways for the lymph drainage, and explain all unexpected clinical observations in the spread of lymphatic metastases. In addition the role of computed tomography and usefulness of positron emission tomography in assessing the nodes is discussed. Finally, we present diagnostic methods, with mediastinoscopy as the best, and we acknowledge the widespread use of the less-invasive endoscopic methods.

NOWOTWORY Journal of Oncology 2016; 66, 1: 53-60

Słowa kluczowe: węzły chłonne, przerzuty raka niedrobnokomórkowego, cecha $\mathrm{N}$

Key words: lymph nodes, non-small cell lung cancer, metastases, N stage

\footnotetext{
${ }^{1}$ Zakład Anatomii Prawidłowej i Klinicznej

Centrum Biostruktury WUM

${ }^{2}$ III Klinika Chorób Płuc

${ }^{3}$ Klinika Chirurgii

${ }^{4}$ Zakład Diagnostyki Obrazowej

Instytut Gruźlicy i Chorób Płuc w Warszawie
} 
Drenaż chłonki z płuc odbywa się poprzez wiele grup węzłów chłonnych, w klasycznym opisie anatomicznym podzielonych na węzły płucne, węzły wnęki płucnej, czyli węzły oskrzelowo-płucne, węzły śródpiersiowe: tchawiczo-oskrzelowe dolne i tchawiczo-oskrzelowe górne, węzły więzadła płucnego oraz węzły przytchawicze; chłonka z płuc może ponadto odpływać do węzłów nadobojczykowych, węzłów mięśnia pochyłego przedniego, które należy uznać za węzły szczytu jamy pachowej [1,2].

Klasyczny opis anatomiczny został w ostatnich kilkudziesięciu latach zastąpiony bardziej szczegółowym podziałem klinicznym. Klasyfikacja zaproponowana przez Naruke w latach 60. XX w. stała się szeroko akceptowana i używana [3, 4].W późniejszych dekadach tworzono kolejne propozycje, najbardziej znanym był podział zaproponowany przez American Thoracic Society i jego modyfikacja, znana jako MD-ATS [5]. Ostatecznie, w celu ujednolicenia dokonywanych ocen zaawansowania choroby nowotworowej, co przekładało się na codzienną praktykę kliniczną, jak również na wyniki publikowanych badań naukowych, ogłoszono w 2009 roku klasyfikację International Association for the Study of Lung Cancer (IASLC). Jest ona podstawą w trakcie diagnostyki i oceny stopnia zaawansowania choroby (zgodnie z systemem TNM) w przypadku podejrzenia bądź potwierdzenia raka niedrobnokomórkowego płuca. Podział ten wyróżnia 14 grup węzłów chłonnych [3, 6, 7] (ryc. 1).

Grupa 1 to węzły szyjne dolne (nadobojczykowe, łącznie z węzłami mięśnia pochyłego przedniego oraz węzłami okolicy wcięcia mostka). Węzły grup 2-4 to węzły śródpiersia górnego: prawe i lewe przytchawicze górne, okołotchawicze (przednaczyniowe i zatchawicze), prawe i lewe przytchawicze dolne. Węzły grupy 5 i 6 wspólnie nazywane są węzłami aortalnymi lub węzłami okna aortalno-płucnego. Jedna grupa związana jest z samym łukiem aorty, kolejna z aortą wstępującą, i niekiedy opisywana jako węzły towarzyszące nerwowi przeponowemu (lewemu). Węzły grup 7-9 to węzły dolnego śródpiersia: węzły podostrogowe oraz grupy znajdujące się poniżej (okołoprzełykowe oraz węzły więzadła płucnego). Grupa ostatnia to węzły związane z wnęką płucną oraz węzły miąższu płucnego, mają one w omawianej klasyfikacji numery 10-14 [3].

Szczegółowe informacje na temat poszczególnych grup węzłów, ich lokalizacji oraz najważniejsze wskazówki topograficzne podano w tabeli I.

Uważa się, że odpływ chłonki z płuca odbywa się dwoma układami naczyń chłonnych — powierzchownym i głębokim. Ten ostatni stanowi drugorzędną drogę odpływu, drenując mniejszą część miąższu płucnego i będąc mniej istotny klinicznie. W układ ten zaangażowane są z pewnością węzły chłonne grup 12-14, a odpływ chłonki odbywa się wzdłuż pęczków oskrzelowo-naczyniowych (zaangażowanie tej drogi jest charakterystyczne m.in. w sarkoidozie). Układ powierzchowny, drenujący większy obszar płuca, składa się z naczyń limfatycznych podopłucnowych, te z kolei zbierają się w większe naczynia zbiorcze i kończą się w węzłach chłonnych oskrzelowo-płucnych, czyli w grupach 10 i 11 wg IASLC [8]. Te węzły stanowią najczęściej pierwszy przystanek szerzenia się choroby nowotworowej drogą chłonną. Uważa się, że odpływ z płata górnego obu płuc i środkowego płuca prawego odbywa się (poprzez węzły wnęki) przede wszystkim do węzłów śródpiersia górnego, w drenażu płatów dolnych obu płuc częściej zaangażowane są węzły dolnego śródpiersia (węzły grup 7-9).

W szeregu przypadków wyniki badań wykazały, że powyższe kanony mogą nie mieć zastosowania. Wiadomym jest, że granice drenażu limfatycznego przekraczają granice segmentów oskrzelowo-płucnych, Topol i wsp. udowodnili istnienie pni chłonnych między poszczególnymi segmentami płata górnego prawego, segmentami języczka oraz między segmentem 5 i 7 w płucu prawym. Zaobserwowali również, że około 7\% naczyń limfatycznych kończy się w węźle chłonnym nieodpowiadającym klasycznemu miejscu drenowania dla danego segmentu [9].

Faries i wsp. w swojej pracy oceniali śródoperacyjny odpływ chłonki z płata operowanego płuca. Ich ustalenia zebrano w tabeli II. Podkreślić należy, że wyników tych nie można traktować wprost, są bowiem jedynie eksperymentalnym potwierdzeniem zaangażowania pewnych (a nie jedynych) grup węzłów w proces odpływu chłonki [10]. Godnym podkreślenia faktem jest charakterystyczny dla płata górnego lewego odpływ chłonki do węzłów okna aortalno-płucnego (grupa $5 \mathrm{i}$ 6), co znalazło swoje odzwierciedlenie w wytycznych oceny stopnia zaawansowania niedrobnokomórkowego raka płuca [11,12]. Uważa się również, że podoopłucnowe fragmenty szczytu płuca prawego mogą być drenowane bezpośrednio do węzłów szczytowych jamy pachowej (grupa 1) [1]. Wreszcie, co również bywa podkreślane w klasycznych opisach anatomicznych, chłonka z płata dolnego lewego ma tendencję do odpływu (poprzez węzły dolnego śródpiersia - głównie grupa 7) do węzłów w górnym śródpiersiu strony prawej i spływu do prawego kąta żylnego [1], czego manifestacją kliniczną są tzw. przerzuty skrzyżowane. Sytuacja ta może dotyczyć nawet $1 / 3$ przypadków [13]. Rzadziej występują przerzuty skrzyżowane pochodzące z płata górnego lewego $[13,14]$.

Powyższe fakty mogą tłumaczyć fenomen przerzutów „z pominięciem” (inaczej „skaczących”), czyli występowania przerzutów w węzłach N2 i równoczesny brak dowodów na zajęcie węzłów grupy N1.W praktyce klinicznej może dotyczyć to od $7 \%$ aż do $26 \%$ pacjentów [3]. Zjawisko to jest charakterystyczne dla raka niedrobnokomórkowego, szczególnie typu gruczołowego [15]. Niektórzy autorzy podkreślają odmienny przebieg i lepsze rokowanie w tej grupie pacjentów [16].

Warto również przytoczyć opisany w literaturze przypadek raka gruczołowego płuca z przerzutami do wewnątrzpłucnych węzłów chłonnych tego samego płuca, czyli grup 
13-14; klinicznie wysunięto podejrzenie przerzutów odległych drogą krwiopochodną — zajęcie węzłów grup 13 i 14 musi więc być brane pod uwagę $w$ diagnostyce różnicowej guzków współistniejących z guzem pierwotnym [17].
„Węzeł wartowniczy", pojęcie dobrze opisane i używane w praktyce chirurgii nowotworów sutka czy czerniaka, nie znalazło do dziś szerokiego zastosowania w operacyjnym leczeniu niedrobnokomórkowego raka płuca mimo kilkuna-
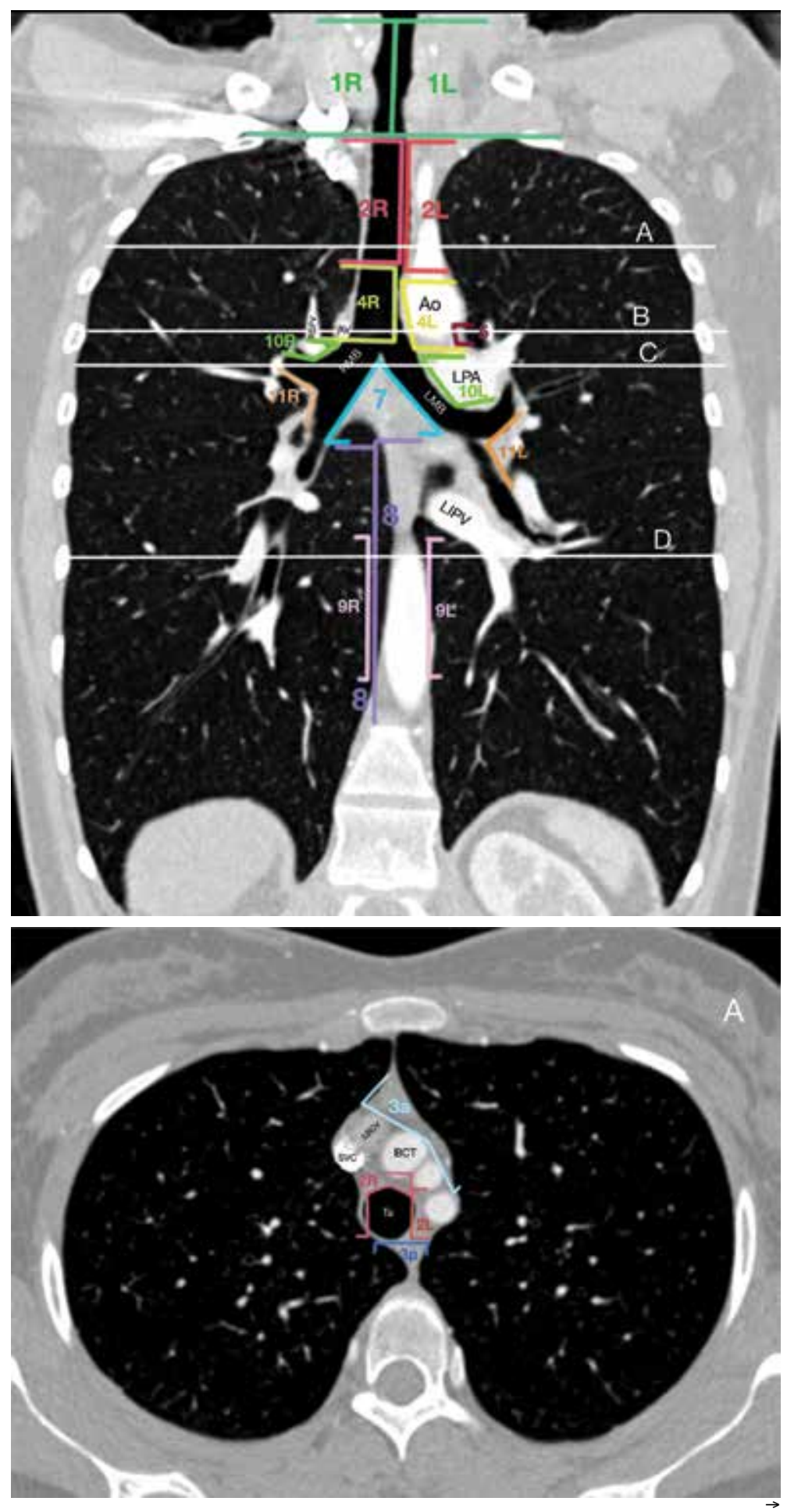

Rycina 1. Lokalizacja poszczególnych grup węzłowych w badaniu tomografii komputerowej w przekroju w płaszczyźnie zbliżonej do czołowej (rycina u góry) i w serii przekrojów w płaszczyźnie poprzecznej (A-D); grupy węzłów chłonnych oznaczone numerami 1-12; Ao — aorta, AV — żyła nieparzysta, BCT — pień ramienno-głowowy, Eo — przełyk, LBCV — lewa żyła ramienno-głowowa, LIPV — lewa żyła płucna dolna, LMB — oskrzele główne lewe, LPA — tętnica płucna lewa; LSPV — lewa żyła płucna górna, RMB — oskrzele główne prawe, RPA — tętnica płucna prawa, RSPV — prawa żyła płucna górna, SVC — żyła główna górna, Ta — tchawica 

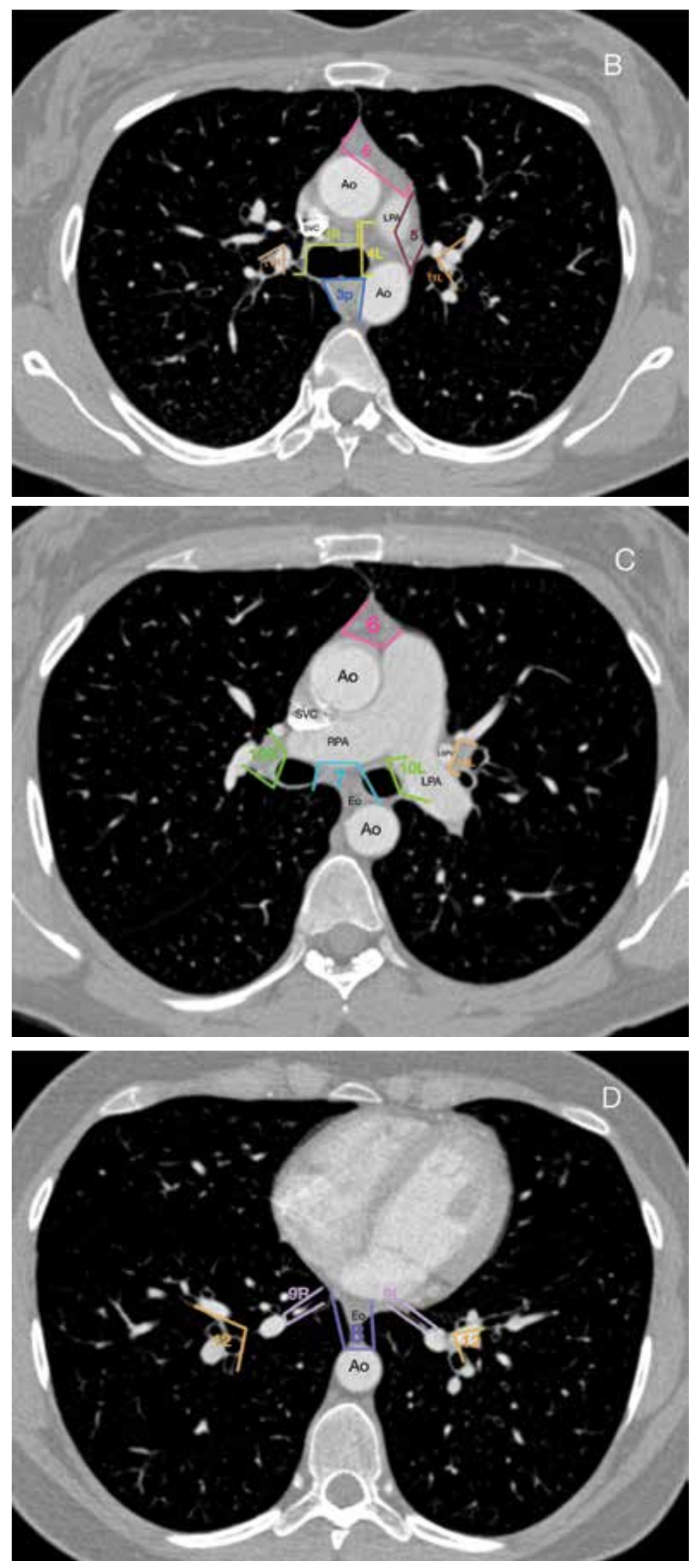

Rycina 1. Lokalizacja poszczególnych grup węzłowych w badaniu tomografii komputerowej w przekroju w płaszczyźnie zbliżonej do czołowej (rycina u góry, s. 55) i w serii przekrojów w płaszczyźnie poprzecznej (A-D); grupy węzłów chłonnych oznaczone numerami 1-12; Ao - aorta, AV — żyła nieparzysta, BCT — pień ramienno-głowowy, Eo — przełyk, LBCV — lewa żyła ramienno-głowowa, LIPV — lewa żyła płucna dolna, LMB — oskrzele główne lewe, LPA — tętnica płucna lewa; LSPV — lewa żyła płucna górna, RMB — oskrzele główne prawe, RPA — tętnica płucna prawa, RSPV — prawa żyła płucna górna, SVC — żyła główna górna, Ta — tchawica 


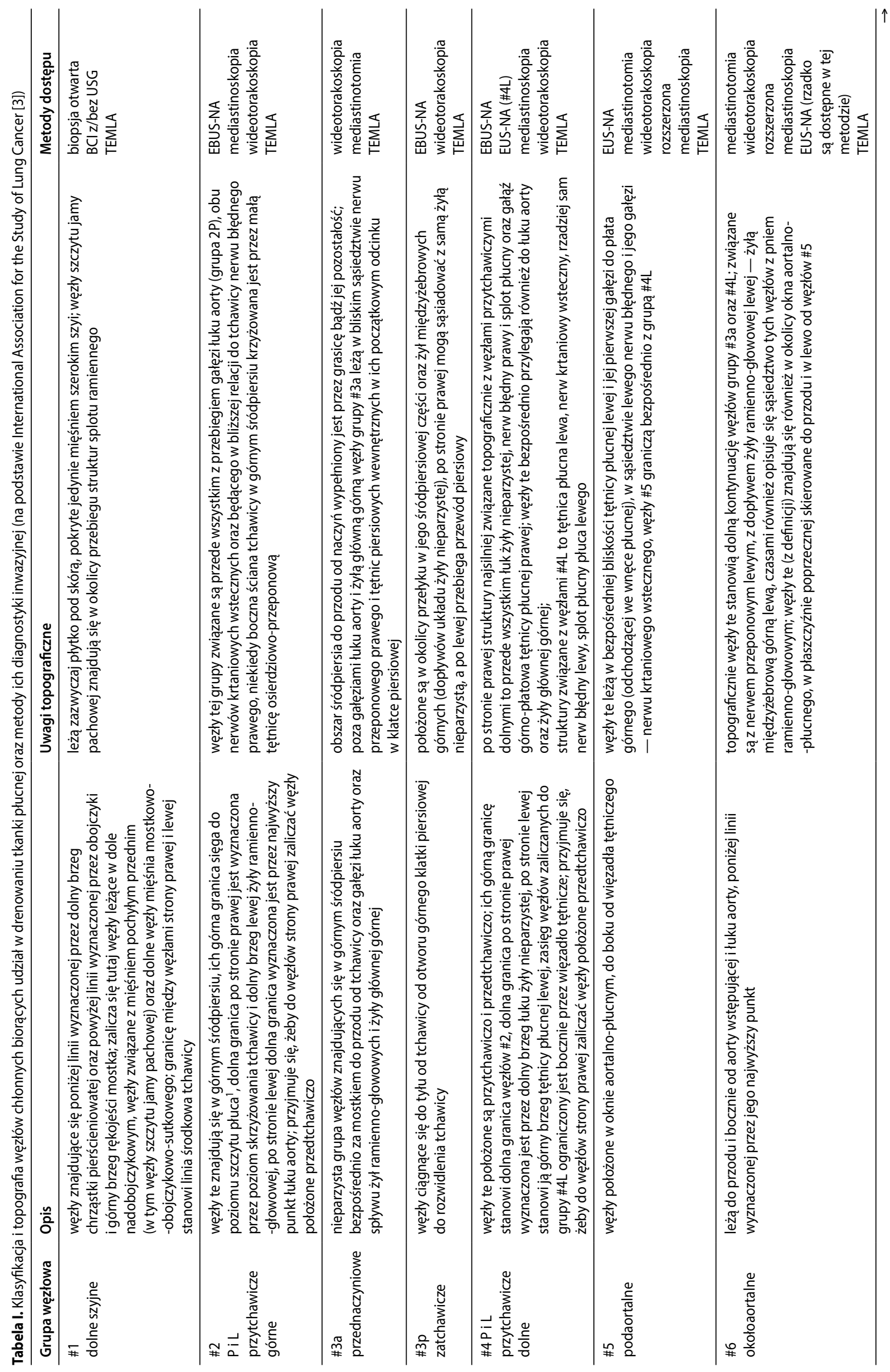




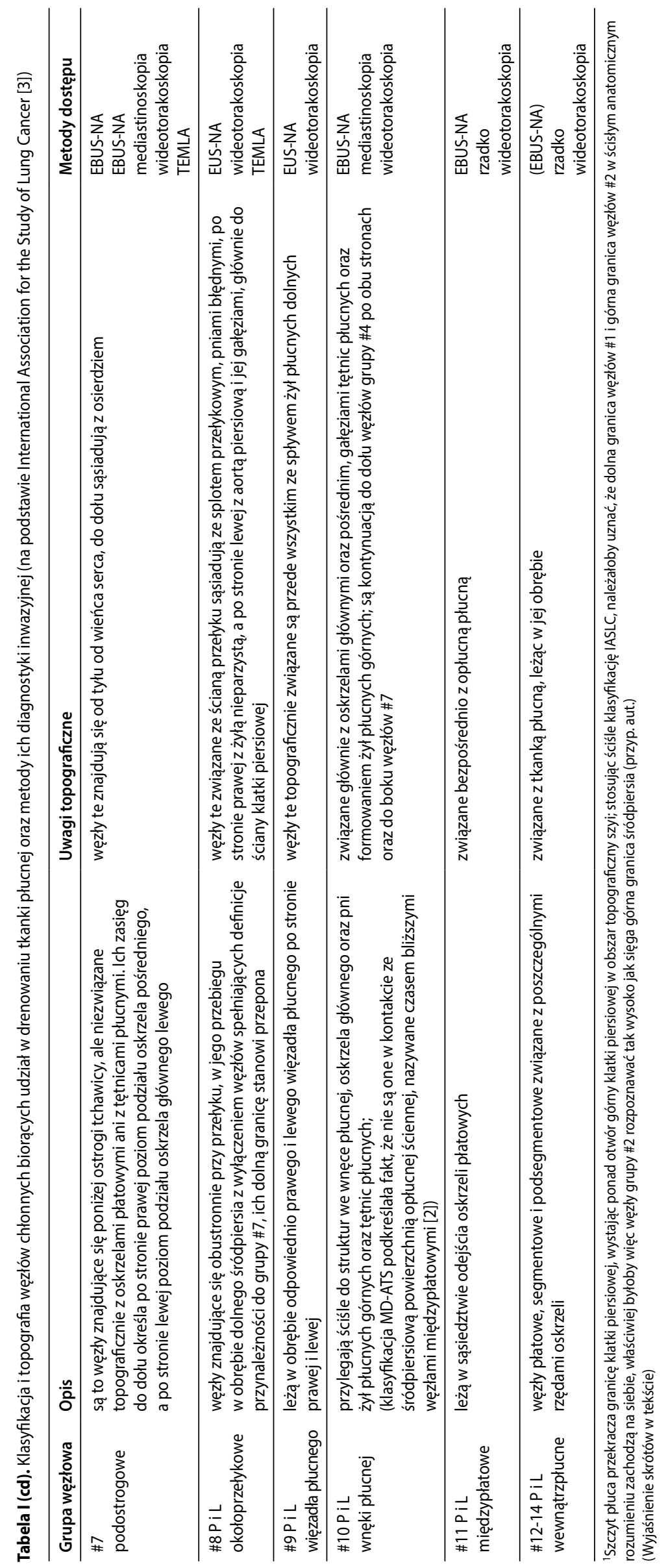


Tabela II. Grupy węzłów chłonnych zaangażowanych w odpływ chłonki z poszczególnych obszarów płuca wg Fariesa i wsp. [10]

\begin{tabular}{ll}
\hline płat górny prawy & $\# 10 \mathrm{R}, \# 8 \mathrm{R}, \# 7, \# 4 \mathrm{R}$ \\
płat środkowy & $\# 10 \mathrm{R}, \# 7, \# 4 \mathrm{R}$ \\
płat dolny prawy & $\# 10 \mathrm{R}, \# 9 \mathrm{R}, \# 8 \mathrm{R}, \# 7$ \\
płat górny lewy & $\# 10 \mathrm{~L}, \# 8 \mathrm{~L}, \# 5, \# 4 \mathrm{~L}$ \\
płat dolny lewy & $\# 10 \mathrm{~L}, \# 9 \mathrm{~L}, \# 8 \mathrm{~L}, \# 4 \mathrm{~L}, \# 2 \mathrm{~L}$ \\
\hline
\end{tabular}

stu badań klinicznych i próby użycia niebieskiego barwnika, radioizotopu Technetu-99, a nawet wykorzystania technik pozytonowej tomografii emisyjnej. Mnogość potencjalnych dróg odpływu chłonki, opisana powyżej, tłumaczy, dlaczego nie udaje się łatwo wytypować jednej stacji węzłowej, która stanowi klucz do określenia węzłowego zaawansowania choroby. Uważa się aktualnie, że zastosowanie radioizotopu z barwnikiem nie może zwalniać z wykonania możliwie doszczętnej limfadenektomii śródpiersiowej, ale wytypowane w ten sposób węzły powinny być obiektem bardziej szczegółowych dociekań patologicznych w poszukiwaniu tzw. mikroprzerzutów raka, na przykład przy użyciu technik molekularnych [18].

W śródpiersiu znajdują się dwa duże pnie chłonne śródpiersiowe (oskrzelowo-śródpiersiowe przednie [2, 19]) oraz mniejsze pnie śródpiersia tylnego; należy pamiętać, że drenują one chłonkę nie tylko z płuc, ale również ze ściany klatki piersiowej i serca. Chłonka odpływa nimi do okolicy kątów żylnych strony prawej i lewej; pień chłonny lewy częściej uchodzi bezpośrednio, ten po stronie prawej częściej współtworzy wspólny pień z przewodem chłonnym prawym i przewodem chłonnym szyjnym prawym [1, 2].

Klasyfikacja TNM służy do oceny stopnia zaawansowania choroby nowotworowej poprzez ocenę 3 cech opisujących istotne aspekty procesu chorobowego: ocenę guza pierwotnego $(T)$, ocenę zmian o charakterze przerzutowym $\mathrm{w}$ regionalnych węzłach chłonnych $(\mathrm{N})$ oraz ocenę przerzutów odległych (M). Ocena cechy $\mathrm{N}$ stanowi najczęściej kluczowe zagadnienie przy określeniu zaawansowania raka niedrobnokomórkowego płuca, decydując niejednokrotnie o zakwalifikowaniu zmiany jako nieresekcyjnej [7]. Wyżej opisane grupy węzłów chłonnych stanowić mogą również źródło materiału cytologicznego i histologicznego, koniecznego do uzyskania rozpoznania. Zasady oceny cechy $\mathrm{N}$ przedstawia tabela III.

Według zaleceń American College of Chest Physicians (ACCP) badaniem podstawowym w ocenie stopnia zaawansowania u pacjenta z potwierdzonym bądź podejrzewanym niedrobnokomórkowym rakiem płuca jest tomografia komputerowa klatki piersiowej (TK), z uwzględnieniem podania kontrastu dożylnego. Czułość i swoistość tej metody w metaanalizie wykonanej przez twórców wytycznych ACCP została obliczona na 55\% i $81 \%$, przy zastosowanym kryterium morfologicznego zaliczenia węzłów jako przerzutowych
Tabela III. Ocena cechy N wg klasyfikacji TNM dla niedrobnokomórkowego raka płuca [6]

\begin{tabular}{ll}
\hline N0 & bez zajęcia regionalnych węzłów chłonnych \\
N1 & $\begin{array}{l}\text { zajęcie węzłów grupy \#10-14 zlokalizowanych po stronie } \\
\text { zmiany pierwotnej }\end{array}$ \\
N2 & $\begin{array}{l}\text { dla zmiany pierwotnej po stronie prawej: zajęcie węzłów } \\
\text { grup \#2R, \#3, \#4R, \#7, \#8R, \#9R } \\
\text { dla zmiany pierwotnej po stronie lewej: zajęcie węzłów grup } \\
\text { \#2L, \#3, \#4L, \#5, \#6, \#7, \#8L, \#9L } \\
\text { N3 zajęcie węztów śródpiersia znajdujących się po stronie } \\
\text { przeciwnej do zmiany pierwotnej oraz każde zajęcie węzłów } \\
\text { grupy \#1 (niezależnie od strony) }\end{array}$ \\
\hline
\end{tabular}

w przypadku krótszego wymiaru przekraczającego $10 \mathrm{~mm}$. TK pozostaje najskuteczniejszą metodą anatomicznej oceny śródpiersia [20].

Badaniem według niektórych konkurującym, według innych uzupełniającym badanie TK jest pozytonowa tomografia emisyjna (PET) z użyciem 18-fluorodezoksyglukozy, obecnie używana w aparatach z tomografią komputerową (PET-TK). Czułość i swoistość tej metody ocenione w metaanalizie wynosiły odpowiednio $80 \%$ i $88 \%$ [11], co ma udowadniać jej wyższość nad klasyczną tomografią komputerową [11, 20, 21].

Dużym ograniczeniem metody PET-TK jest brak standardowej wartości punktu odcięcia współczynnika wychwytu znacznika (standard uptake value, SUV). Stosowana w większości badań jest wartość większa od 2,5, jednak jest ona oparta na podstawach teoretycznych dla zmian pierwotnych znajdujących się obwodowo, o wymiarze przekraczającym $2 \mathrm{~cm}$ [11]. Wiadomo również, że metabolizm komórek nowotworu o typie gruczołowym jest znacząco różny, co może się przekładać na zmniejszenie wartości SUV tych komórek [11].

Wytyczne ACCP jednoznacznie wskazują konieczność wykonywania badań inwazyjnych w celu weryfikacji przypisania do grupy zaawansowania klinicznego na podstawie TK lub PET-CT [11]. Co należy jednoznacznie podkreślić: wybór metody inwazyjnej diagnostyki zależy wyłącznie od lokalizacji anatomicznej zmian podejrzanych, a nie od ich metabolicznej aktywności bądź jej braku [11].

Najwyższa grupa węzłowa (grupa 1) pierwotnie diagnozowana była drogą biopsji otwartej. Obecnie metoda ta wyparta została przez biopsję cienkoigłową. Jest ona najczęściej wykonywana pod kontrolą sondy USG, jednak w przypadku palpacyjnie wyczuwalnych węzłów możliwa jest również biopsja bez używania ultrasonografu.

Przez wiele lat złotym standardem w diagnostyce węzłów chłonnych śródpiersia pozostawała mediastinoskopia. Wprowadzona została w 1959 roku przez Carlensa, a w latach dziewięćdziesiątych zastąpiła ją wideomediastinoskopia. Dzięki tej operacji możliwe jest pobranie wycinków z węzłów grup 2R, 2L, 4R, 4L, 7, 10L, 10R. Metoda ta doczekała się kilku modyfikacji. Zalicza się do nich m.in. mediastinoskopię 
rozszerzoną (modyfikacja Kirchnera lub Ginsberga), dzięki której uzyskuje się dodatkowo dostęp do węzłów grup 5 i 6. To jednak metody znacznie rzadziej stosowane, głównie ze względu na dużo większą inwazyjność i tym samym większe ryzyko poważnych powikłań [13].

Pochodną mediastinoskopii jest przezszyjna rozszerzona limfadenektomia śródpiersia (transcervical extended mediastinal lymphadenectomy, TEMLA), rzadko stosowany zabieg rozległego usunięcia węzłów chłonnych śródpiersia wraz z otaczającym tłuszczem śródpiersiowym. Dzięki cięciu kołnierzowemu uzyskuje się tu dostęp do węzłów grupy 1, a dzięki uniesieniu mostka ku górze przez specjalny hak możliwe jest usunięcie węzłów 2, 4, 5, 6, 7, 8. TEMLA umożliwia pobranie węzłów 3a i 3p, ale wykonywane jest to sporadycznie [22].

Dostęp do węzłów grupy 5, 6 oraz 3a uzyskać można drogą mediastinotomii, wykonywanej najczęściej na wysokości 2.-3. chrząstki żebrowej w linii przymostkowej lewej lub wideotorakoskopii lewostronnej. Dzięki wideotorakoskopii mamy w zasadzie dostęp do wszystkich grup węzłowych, ale ograniczeniem jest jej inwazyjność oraz to, że podczas zabiegu wykonywanego po jednej stronie nie mamy dostępu do węzłów strony przeciwnej.

Opisane wyżej chirurgiczne metody diagnostyki węzłów chłonnych śródpiersia ustępują stopniowo pola technikom małoinwazyjnym. Szeroko stosowane od kilku lat badania bronchofiberoendosonograficzna aspiracyjna biopsja igłowa (EBUS-NA) i endosonograficzna przezprzełykowa aspiracyjna biopsja igłowa (EUS-NA) zdążyły już ugruntować swoją pozycję jako badania wysoce czułe i swoiste, a jednocześnie dające niski odsetek powikłań. Dzięki zastosowaniu techniki EBUS-NA uzyskujemy dostęp do węzłów grup 2, 3p, 4, 7, 10, 11, 12, EUS-NA umożliwia natomiast biopsję węzłów 4L, 5, $7,8,9$ oraz bardzo rzadko (i tylko fragmentarycznie) grupy 6. Często obie te techniki są chętnie stosowane łącznie podczas tego samego znieczulenia pacjenta. Podsumowanie możliwych dostępów i sposobów diagnostycznych do omawianych grup węzłów chłonnych znajduje się w tabeli I [23].

\section{Konflikt interesów: nie zgłoszono}

\section{Lek. Mateusz Polaczek}

OddziałX

Instytut Gruźlicy i Chorób Płuc

ul. Płocka 26, 01-138 Warszawa

e-mail:polaczek@me.com

Otrzymano: 13 października 2015 r.

Przyjęto do druku: 2 grudnia 2015 r.

\section{Piśmiennictwo}

1. Moore KL, Dalley AF, Agur AM. Clinically oriented anatomy. Baltimore: Lippincott Wiliams \& Wilkins; 2014, s. 71-180.

2. Terminologia Anatomica: International Anatomical Terminology FCATFederative Committee on Anatomical Terminology. Stuttgart:Thieme; 1998.

3. Rusch VW, Asamura H, Watanabe H i wsp. The IASLC lung cancer staging project: a proposal for a new international lymph node map in the forthcoming seventh edition of the TNM classification for lung cancer. J Thorac Oncol 2009; 4: 568-577.

4. NarukeT, Suemasu K, Ishikawa S. Lymph node mapping and curability at various levels of metastasis in resected lung cancer.J Thorac Cardiovasc Surg 1978; 76: 832-839.

5. Mountain CF, Dresler CM. Regional lymph node classification for lung cancer staging. Chest 1997; 111: 1718-1723.

6. Detterbeck FC, Postmus PE, Tanoue LT. The stage classification of lung cancer: diagnosis and management of lung cancer: American College of Chest Physicians evidence-based clinical practice guidelines. 3rd. Ed. Chest 2013; 143 (5 Suppl): e191S-e210S.

7. Orłowski T, Rzyman W. Chirurgiczne leczenie niedrobnokomórkowego raka płuca. W: Jassem J, Krzakowski M (red.) Nowotwory płuca i opłucnej. Gdańsk: Via Medica; 2009, s. 74-86.

8. Gołąb B. Recognition of the lymphatic vessels. Folia Morphol 1970 29: 33-38.

9. Topol M, Masłoń A. Some variations in lymphatic drainage of selected bronchopulmonary segments in human lungs. Ann Anat 2009; 191: 568-574.

10. Faries $\mathrm{MB}$, Bleicher RJ, Ye X i wsp. Lymphatic mapping and sentinel lymphadenectomy for primary and metastatic pulmonary malignant neoplasms. Arch Surg 2004; 139: 876-877.

11. Silvestri GA, Gonzalez AV, Jantz MA i wsp. Methods for staging non-smal cell lung cancer: diagnosis and management of lung cancer. 3rd. Ed. American College of Chest Physicians evidence-based clinical practice guidelines. Chest 2013; 143 (5 Suppl): e250S.

12. Cerfolio RJ, Bryant AS. Distribution and likelihood of lymph node metastasis based on the lobar location of nonsmall-cell lung cancer. Ann Thorac Surg 2006; 81: 1969-1973.

13. Patterson GA, Pearson FG, Cooper JD i wsp. Pearson's Thoracic and Esophageal Surgery. 3rd. Ed. Philadelpha: Elsevier, 2008.

14. Hoshikawa M, Mochizuki H, Saito M i wsp. Contralateral cervicomediastinal lymph node metastases from clinically occult adenocarcinoma of the lung. Clin Lung Cancer 2009; 10: 249-251.

15. Libshitz HI, McKenna RJ, Mountain CF. Patterns of mediastinal metastases in bronchogenic carcinoma. Chest 1986; 90: 229-232.

16. Prenzel KL, Mönig SP, Sinning JM i wsp. Role of skip metastasis to mediastinal lymph nodes in non-small cell lung cancer. J Surg Oncol 2003; 82: 256-260

17. Masuya $D$, Gotoh $M$, Nakashima T i wsp. A surgical case of primary lung cancer with peripheral intrapulmonary lymph node metastasis. Ann Thorac Cardiovasc Surg 2007; 13: 53-55.

18. Shersher DD, Liptay HJ. Status of sentinel lymph node mapping in non-small cell lung cancer. Cancer $J 2015 ; 21: 17-20$

19. Reicher M, Łasiński W. Płuca. W: ŁasińskiW (red.) Anatomia człowieka VIII. Warszawa: Wydawnictwo Lekarskie PZWL; 2013, s. 441-443.

20. Lee JW, Kim BS, Lee DS i wsp. 18F-FDG PET/CT in mediastinal lymph node staging of non-small-cell lung cancer in a tuberculosis-endemic country: consideration of lymph node calcification and distribution pattern to improve specificity Eur J Nucl Med Mol Imaging 2009; 36: 1794-1802.

21. Opoka L. Diagnostyka raka płuca i ocena zaawansowania metoda tomografii komputerowej i FDG PET/CT. Rozprawa doktorska. Warszawa: Instytut Gruźlicy i Chorób Płuc; 2010.

22. Zieliński M, Hauer L, Hauer J i wsp. Transcervical extended mediastinal lymphadenectomy (TEMLA) for staging of non-small-cell lung cancer (NSCLC). Pneumonol Alergol Pol 2011; 79: 196-206.

23. De Leyn P, Dooms C, Kuzdzal J i wsp. Preoperative mediastinal lymph node staging for non-small cell lung cancer: 2014 update of the 2007 ESTS guidelines. Trans/ Lung Cancer Res 2014; 3: 225-233. 